\title{
IMPACT OF COMMUNICATION BARRIERS ON URBAN DEVELOPMENT OF NOWOGRÓD BOBRZAŃSKI
}

\author{
Janusz LASKOWSKI ${ }^{1}$, Artur JUSZCZYK ${ }^{2}$ \\ University of Zielona Góra, Zielona Góra, Poland
}

\begin{abstract}
Network communication links is an indispensable element of development shaping. Any change in the way of using area should be preceded by an analysis of future impact taking into account the transport capacity. The development of buildings without adequate communication links leads to restrictions on object access, consequently it may lead to dangerous mishaps. Avoiding this type of situation is possible by carrying out sustainable development.

The paper describes the relationship between the road system and urban layout on the example of Nowogród Bobrzański part of the city. One presented existing changes in the transportation system and its impact on local residents.
\end{abstract}

Keywords: communication, urban layout, roads, Nowogród Bobrzański

\section{INTRODUCTION}

The communication infrastructure and urban layout are directly linked elements. In cities history, issues proper internal communications as well as communication links with the proximal and distal surrounding have always been at the core of the development of urban systems [2]. Expansion or

\footnotetext{
${ }^{1}$ Corresponding author: University of Zielona Gora, Faculty of Building, Architecture and Environmental Engineering, Z. Szafrana st 1, 65-516 Zielona Góra, Poland, e-mail: j.laskowski@ib.uz.zgora.pl, tel. +48683287343

2 Corresponding author: University of Zielona Gora, Faculty of Building, Architecture and Environmental Engineering, Z. Szafrana st 1, 65-516 Zielona Góra, Poland, e-mail: arturjuszczyk@o2.pl, tel. +48683284784
} 
revitalization of the building should be preceded by an analysis of the road system communications capabilities and its possible adjustment. Most often it happens differently. The first stage is formed buildings and then public transport links are built. Such practices lead to difficulties in the use of areas in the first period and in subsequent preparation of road projects. Described example of communication infrastructure and urban system in Nowogród Bobrzański do not fit into any of the above ideas. The original spatial and urban arrangement properly met the needs of residents. As a result of changes it was disrupted, buildings still grew and communication was limited by existing railway embankment.

\section{HISTORICAL OUTLINE OF THE TOWN}

The town of Nowogród Bobrzański was established on 1 January 1988, with the merger of two villages located on opposite banks of the river Bóbr: Nowogród Bobrzański and Krzystkowice [4].

The first reference of Nowogród Bobrzański already appeared in 1202. A medieval town was situated on a steep right bank of the river Bóbr in the area of crossing the river. The location in the vicinity of the road Żagań-Zielona Góra, being one of the branches of the Solny Route, contributed to the development of the town, the consequence of which was to obtain municipal rights in the thirteenth century. Neighbouring Krzystkowice was established probably later, it received city rights in 1659 . The original urban layout reflected, on the set, a letter ' $\mathrm{C}$ ' with an irregular four-sided market square. Currently there are only fragments of it. Over the centuries, there emerged and became destroyed various river crossings, linking the neighbouring villages. In 1895 a railway line to Bieniów and Żary was activated, a few years later a connection to Zielona Góra was opened. Founded in that time railway route had been properly harmonized with the existing buildings and a new intersection with the earlier road infrastructure provided full communication.

Destruction at the end of World War II and projects immediately afterwards, changed buildings dramatically along with the communication system. 


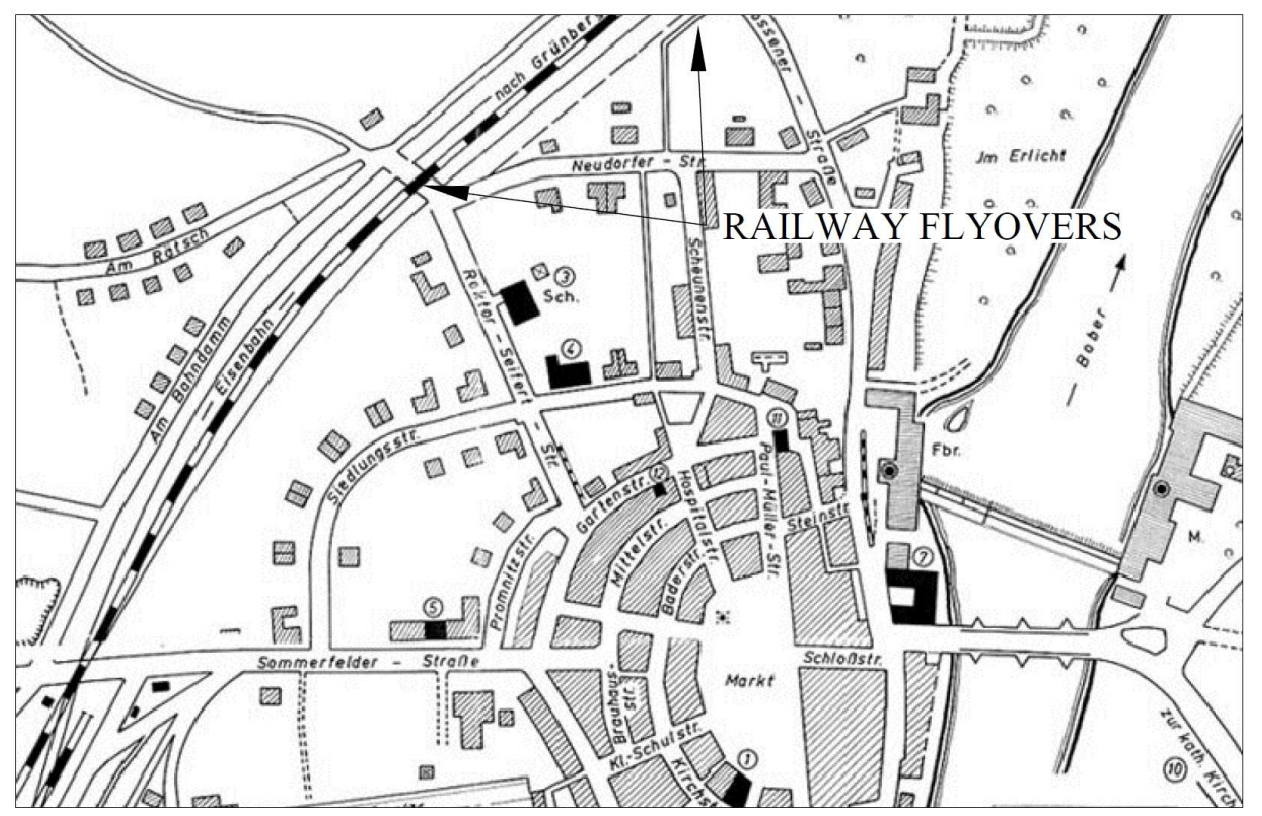

Fig. 1. The plan of communication system in Krzystkowice in the early twentieth century [3]

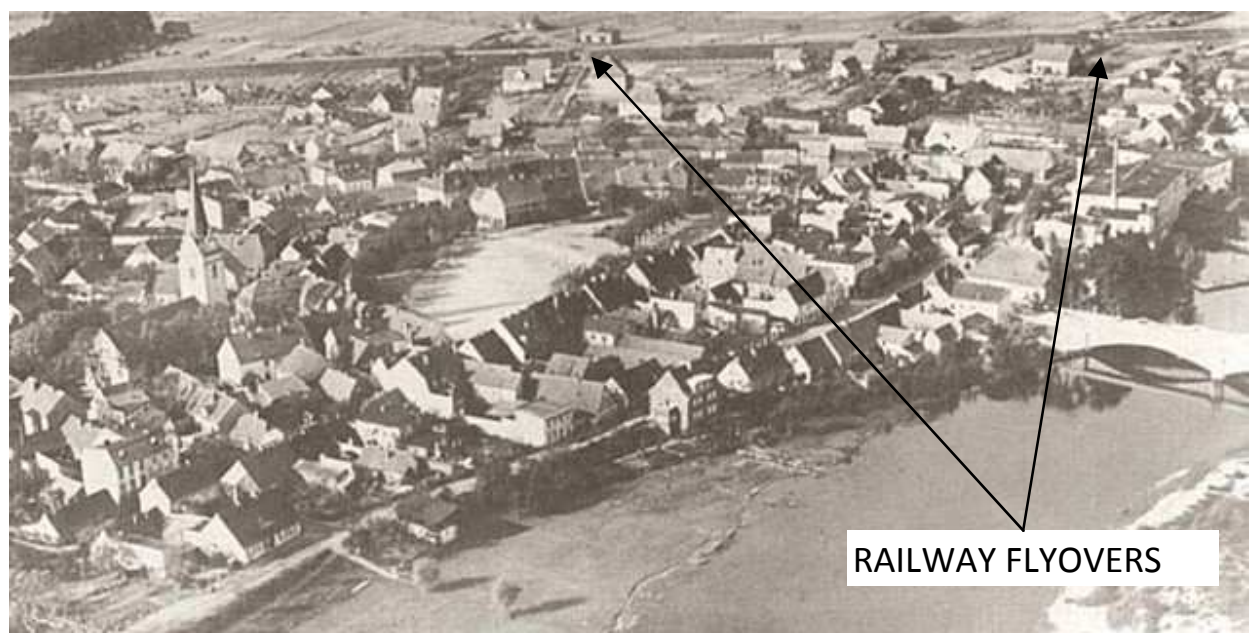

Fig. 2. View of flyovers in the panorama background of the town in the early twentieth century [3] 


\section{TRANSFORMATION OF COMMUNICATION SYSTEM}

The central part of the old Krzystkowice had original communications of radialcircuit system. Built in the late nineteenth century railway route cut the built-up area of Nowogród Bobrzański, not crucially disturbing the original urban layout of the town. Two flyovers were completed, over the Marcinkowski street (then Rektor - Seifert Straße) and General Walter street (former Crossenstraße), which provided good conditions for communication at that time. After World War II the first of the buildings was demolished. The reasons are unknown; it could probably have been destroyed or seriously damaged during hostilities. From that moment on access beyond railroad was allowed by viaduct along the street of General Walter (Fig. 3) and the railroad crossing at the Pocztowa street. The distance between these places is more than $700 \mathrm{~m}$. The characteristic values of an existing railroad object is composed of: brick frontons, steel open bridge, vertical light $-4.4 \mathrm{~m}$, horizontal light $-5.9 \mathrm{~m}$, which do not provide the required gauge for two-way car traffic. There is also no dedicated pavement within the overpass. It can be assumed that the adjacent overpass had a similar geometry and structure.

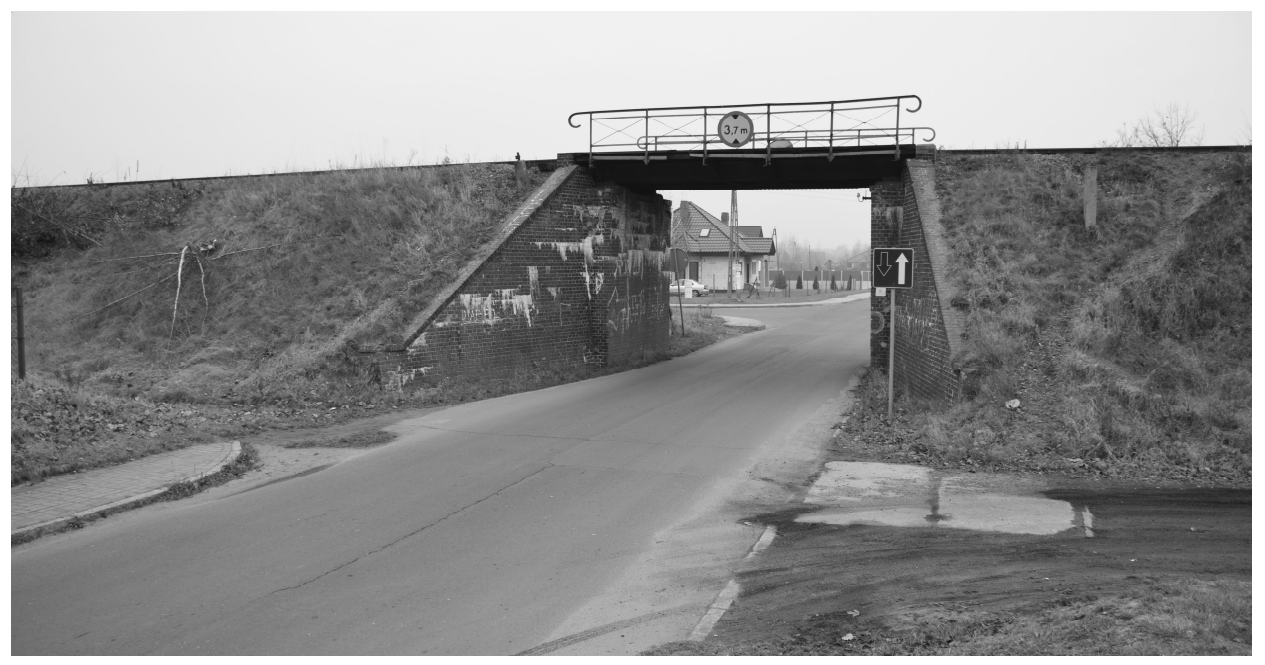

Fig. 3. View the railway viaduct over the street of General Walter

However, this did not stop the further development of the building. Due to established communication barriers housing developments, on the north of the railway embankment, were shaped in a rectangular pattern very closely linked with the street of General Walter, which can be seen on the key plan (Fig. 4). 
Residents, shortening the path to the centre, marked out their own path through the embankment and rail tracks. Of course, this was not a safe solution, whereby there were several accidents.

The need to change the road system resulted from the continuous development of housing construction in this area. For local residents, railway line situated on the embankment was a barrier to access to the centre of the town. In response, a new connection was designed in the form of the underpass under the railway embankment. The tunnel was made in a place where the earlier path ran across the tracks (Fig. 5), between the streets of Nowowiejska and Tama Kolejowa. The new sequence has changed the existing communication network (Fig. 4).

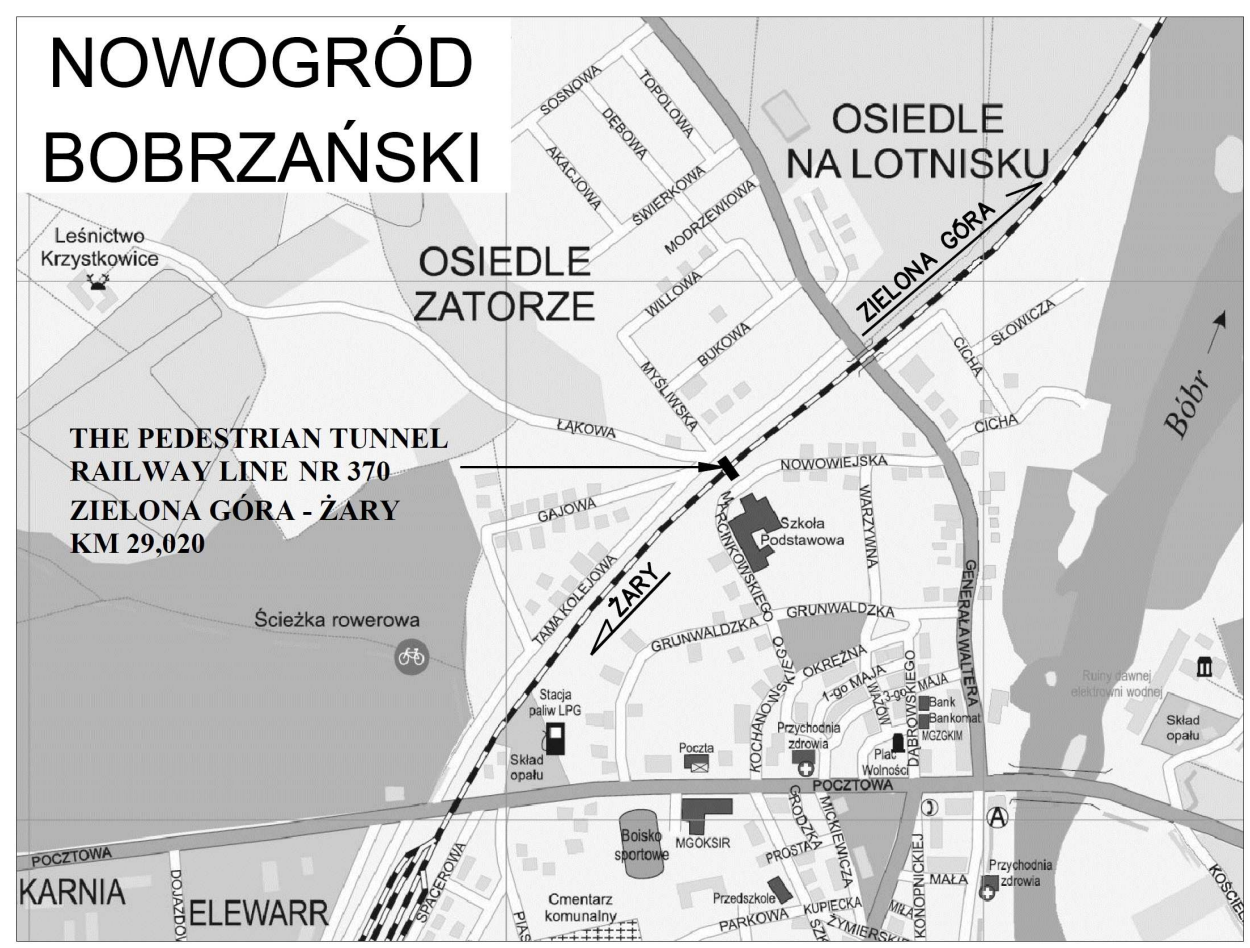

Fig. 4. The indicative plan of the communication system of Nowogród Bobrzański fragment and the location of a pedestrian crossing under railways 


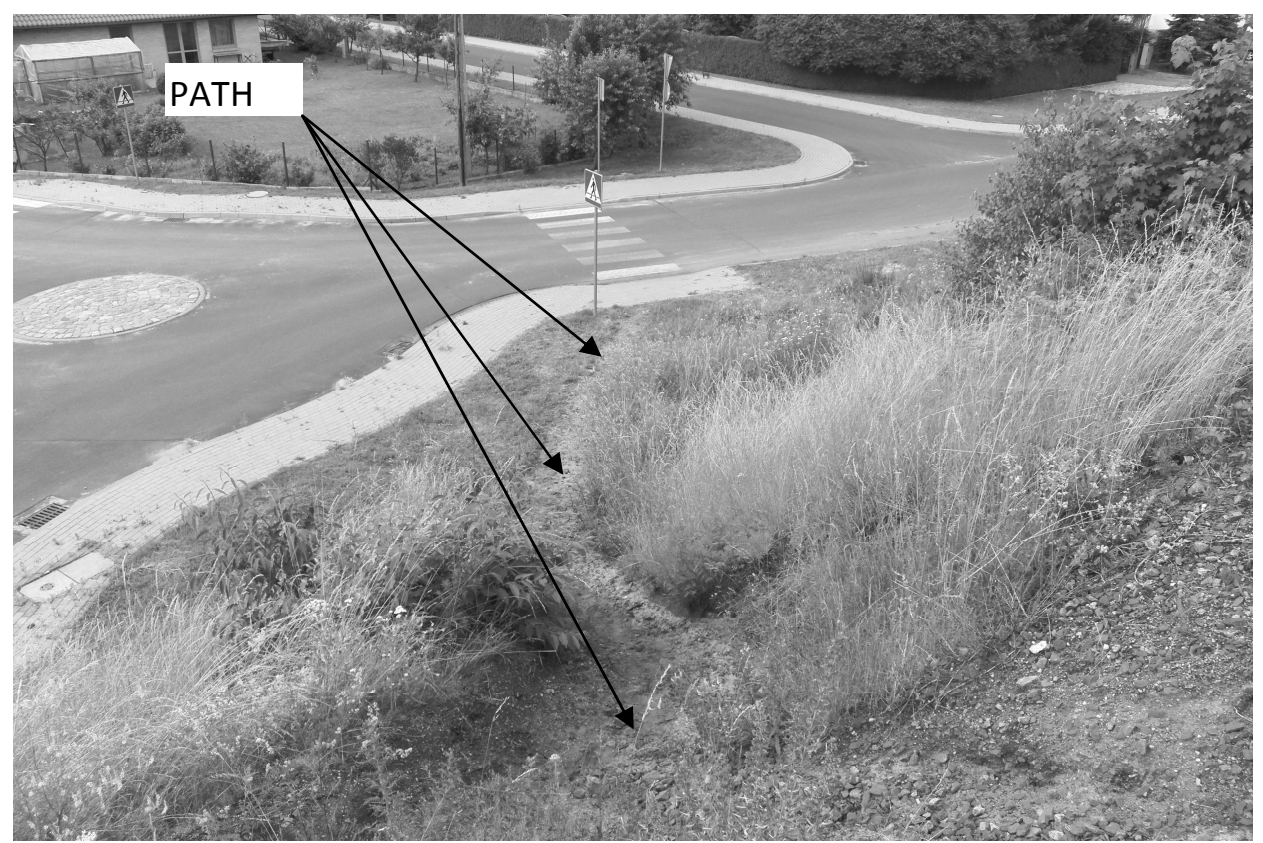

Fig. 5. View the path trodden by pedestrians on the railway embankment

Change of the transportation system by building a pedestrian tunnel had been beneficial, not only to solve communication problems, but also to improve the aesthetics of the area (Fig. 6).

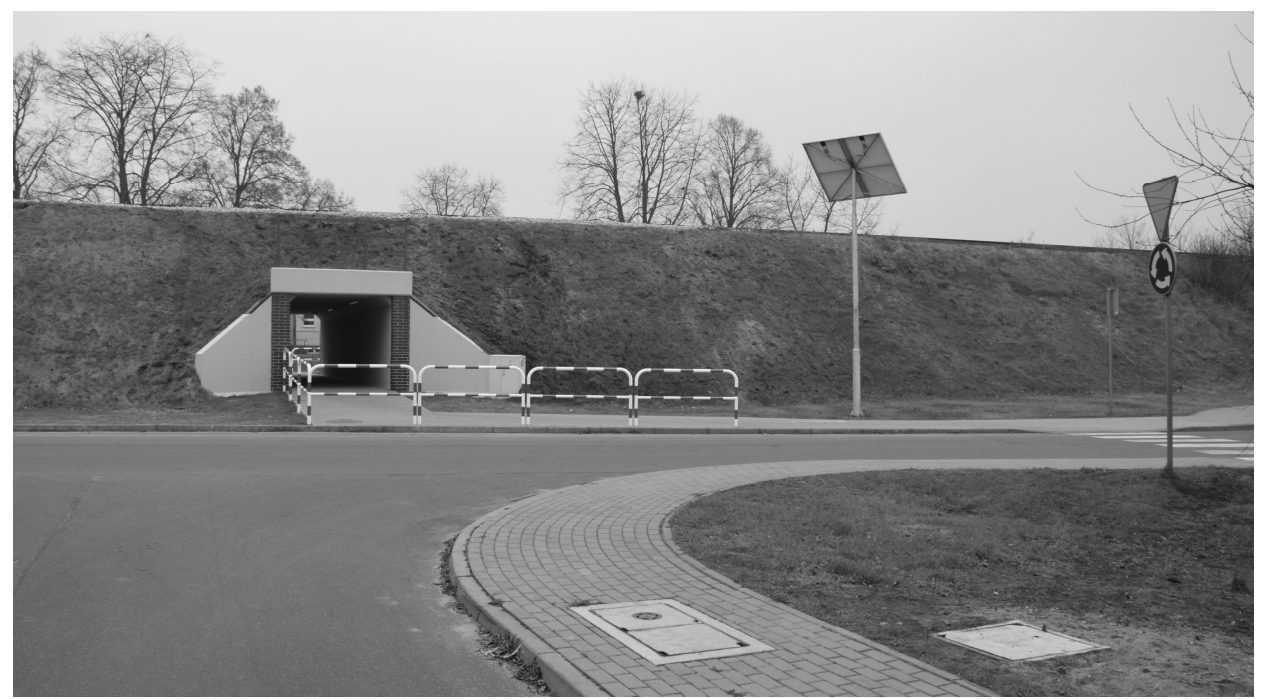

Fig. 6. View of a pedestrian crossing built under the railway embankment 


\section{URBAN DEVELOPMENT}

The present road system within the north-western Nowogród Bobrzański meets the basic local communication needs. The attractiveness of the area in terms of nature and geography in the future can contribute to the urban development in this area and, consequently, will require infrastructure changes. Additional factors increasingly determining the transformation of the road network is a constantly growing level of expectation in terms of road safety and availability of goods and services.

When planning the urban development of Nowogród Bobrzański areas located behind the railway line it is necessary to analyze the following assumptions:

- reconstruction of the bridge above General Walter street to ensure the safe passage of vehicles and pedestrians;

- construction of an additional overpass, meeting the requirements of technical conditions;

- waterfront restoration of Bóbr as a walking part of the town.

Finally, the need for change depends on the demographic growth of the local community [1].

\section{CONCLUSIONS}

The cultural and material growth influences urban development stimulatingly. The communication system is a key element to the proper use of the adjacent properties. Urban development should be planned in a sustainable way. Realized linear infrastructure can often limit the movement of people as well as free migration of animals. Unfortunately, there are still many areas where the people, as a result of earlier own actions, have problems with safe mobility. An example of such a situation until recently, over half a century, was the northwestern part of the town of Nowogród Bobrzański. It should be noted that the construction of a pedestrian crossing under the railway embankment and the related change of communication system in this part of the town contributed substantially to the safety of local residents. Characteristically situated estate "Zatorze", in Nowogród Bobrzański on the northern side of the railway line, developed without the possibility of a safe passage of residents to the centre of the town. The strategic objective of the new merger was to increase pedestrian safety and improve the attractiveness of built-up area. The investment significantly raised the level of safety in rail transport. The alteration of road system in the area of housing development will help to meet the needs of the local community and is a component in the pursuit of appropriate standards of urban development. 
People's expectations in terms of transport are changing with the development of civilization. As a consequence, "today's" transportation system in some time may not comply with current standards and there will be a need for retransformation.

\section{REFERNCES}

1. Czarnecki W.: Planowanie miast i osiedli, PWN, Warszawa 1970.

2. Kochański P.: Rewitalizacja starego miasta w Kożuchowie - nowe zdefiniowanie uktadu komunikacyjnego, Renowacja budynków i modernizacja obszarów zabudowanych. T. 4 red. T. Biliński, Oficyna Wydaw. Uniwersytetu Zielonogórskiego, Zielona Góra 2008, 177-188.

3. Krzystkowice [online]. [dostęp: 10.12.2014]. Dostępny w internecie: krzystkowice.eisp.pl

4. Nowogród Bobrzański [online]. [dostęp: 10.12.2014].Dostępny w internecie: nowogrodbobrz.pl

\section{WPŁYW UKŁADU KOMUNIKACYJNEGO NA PRAWIDŁOWY ROZWÓJ URBANISTYCZNY NA PRZYKŁADZIE NOWOGRODU BOBRZAŃSKIEGO}

\section{Streszczenie}

Sieć połączeń komunikacyjnych jest nieodzownym elementem kształtującym zabudowę. Każdą zmianę sposobu użytkowania obszaru powinna poprzedzać analiza przyszłego oddziaływania z uwzględnieniem możliwości transportowych. Rozwój zabudowy bez odpowiednich połączeń komunikacyjnych prowadzi do ograniczeń dostępności do obiektu, następstwem czego może dojść do niebezpiecznych zdarzeń losowych. Uniknięcie tego typu sytuacji możliwe jest dzięki prowadzeniu zrównoważonego rozwoju.

W artykule opisano zależność pomiędzy systemem drogowym i układem urbanistycznym na przykładzie fragmentu miasta Nowogród Bobrzański. Zaprezentowane zostały zmiany układu komunikacyjnego i ich wpływ na użytkowników.

Słowa kluczowe: komunikacja, układ urbanistyczny, drogi, Nowogród Bobrzański 